\title{
Repetitive transcranial magnetic stimulation improves neurological function after cerebral ischemia in rats by increasing CREB-regulated TrkB via activation of cAMP/PKA and Ca2+/CaMKIV signaling pathways
}

\section{Lisha Chang}

North China University of Science and Technology Affiliated Hospital

\section{Zhaowang An}

North China University of Science and Technology Affiliated Hospital

Jiang Zhang

North China University of Science and Technology Affiliated Hospital

Fuling Zhou

North China University of Science and Technology Affiliated Hospital

\section{Dali Wang}

North China University of Science and Technology Affiliated Hospital

Jian Liu

North China University of Science and Technology Affiliated Hospital

Yunhe Zhang ( $\boldsymbol{\sim}$ zhangyunhezyh@yeah.net)

North China University of Science and Technology Affiliated Hospital

\section{Research}

Keywords: Cerebral ischemia, Neurological function, Repetitive transcranial magnetic stimulation, cAMPresponse element binding protein, cAMP/PKA pathway, Ca2+/CaMKIV pathway, Tropomyosin-related kinase $B$

Posted Date: August 11th, 2020

DOI: https://doi.org/10.21203/rs.2.17132/v2

License: (c) (1) This work is licensed under a Creative Commons Attribution 4.0 International License.

Read Full License 
The authors have withdrawn this preprint from Research Square 